\title{
The heterogeneous effect of software patents on expected returns: evidence from India*
}

\author{
Markus Eberhardt $^{a} \quad$ Marcel Fafchamps $^{b}$ \\ Christian Helmers $^{c} \quad$ Manasa Patnam ${ }^{d}$ \\ ${ }^{a}$ University of Nottingham \\ ${ }^{b}$ Stanford University \\ ${ }^{c}$ Santa Clara University \\ ${ }^{d}$ CREST (ENSAE)
}

April 21, 2016

\begin{abstract}
We contribute to the literature on the role of patenting for economic development by analyzing the impact of patent protection for software in India. We find that a proposed broadening of patent eligibility to include software in 2004 had a large positive effect on average returns for listed software companies in India. An unanticipated reversal of this proposed policy change in 2005 resulted in substantial negative returns. We illustrate substantial heterogeneity in the dynamics of these effects across the sequence of events. We also find smaller firms to have been systematically and most significantly affected by the tightening of patent law with regard to software patents.
\end{abstract}

Keywords: Patents, software, innovation, India

JEL Classification: D22, O14, O34, O38

\footnotetext{
${ }^{*}$ Correspondence: Christian Helmers, Department of Economics, Santa Clara University. Email: chelmers@scu.edu
} 


\section{Introduction}

There is a long-standing yet unsettled debate on the effect of intellectual property (IP) rights, in particular in form of patents, on innovation and economic development (Nordhaus, 1969; Helpman, 1993; Grossman and Lai, 2004). One strand of this debate focuses on the impact of patents on innovation in high-tech industries, mostly in advanced economies (Scherer and Weisburst, 1995; Sakakibara and Branstetter, 2001; Jaffe and Lerner, 2004), whereas another analyzes the role that patents can play for economic development in emerging and developing economies (Penrose, 1973; Chen and Puttitanum, 2005; Hu and Jefferson, 2009).

Our study relates to both of these strands by providing empirical evidence for the effect of various changes in the Indian patent law which affected patent eligibility of software. In India, software per se is explicitly excluded from patentable subject matter. In December 2004, however, the Indian government announced an ordinance that aimed to substantially loosen the restrictions on the patent eligibility of software. The proposed ordinance was unexpectedly rejected by parliament in April 2005, with the result that the original restrictions remained in place. Since neither of these events were anticipated we can treat them as natural experiments and hereby provide a causal link between patentability and the economic value of patents, measured as 'abnormal' stock market returns for the affected software companies.

Our findings show that the announcement of a loosening of the restrictions on patentability, on average, resulted in significant positive stock market returns for affected companies. When parliament rejected the proposed change four months later, we observe again, on average, positive returns. This counter-intuitive result is explained by substantial heterogeneity in these effects. When the ordinance was announced in 2004, positive returns for a subset of companies dominated. When the ordinance was rejected in 2005, those companies that had seen negative returns in 2004 experienced positive returns that outweighed the drop in returns for the subset of companies that had experienced positive returns in 2004. This reversal of fortunes suggests that the stock market expected some software companies to capitalize on an improved ability to protect software inventions through patents. In fact, when the Indian intellectual property office reinforced the restrictions on the patentability of software later in 2005, those companies experienced again substantial stock market losses.

Our analysis contributes to the existing literature on innovation by offering empirical evidence on the impact of changes in the availability and strength of patent protection on companies in a developing economy. Most of the existing literature on IP in developing markets focuses either on pharmaceutical patents (Arora et al., 2009; Sampat, 2010; Arora et al., 2011; Kyle and Qian, 2013) or relies on cross-country analysis (Lerner, 2002, Kanwar and Evenson, 2003; Qian, 2007, Hu and Png, 2013). Our study provides evidence on the effect of patents on private returns in a highly-innovative industry that has contributed enormously to India's recent economic growth 1

\section{Software Patents in India}

A 2002 amendment to India's 1970 Patents Act excluded software from patent eligibility. According to this amendment, inventions in the form of "a mathematical or business method or a computer programme per se or algorithms" (Section 3(k) amended Patents Act) are not patent eligible. This meant that software on its own cannot be patented, although software in combination with hardware may be patentable.

\footnotetext{
${ }^{1}$ Software accounts for around $12-16 \%$ (depending on industry definition) of total Indian exports (2010/11) and employs around 2.5 million mostly skilled workers (UNCTAD, 2012).
} 
In December 2004 the Indian government issued an ordinance which stated that the clause governing software patentability added in 2002 should be modified to exclude "a computer programme per se other than its technical application to industry or a combination with hardware" [emphasis added]. Hence, it explicitly opened the possibility for software to be patent eligible provided it had technical application. The proposed amendments would have had a major impact on the granting practice of software patents. However, parliament unexpectedly rejected this modification and the amendment adopted in April 2005 did not include the software-related amendment put forward in the ordinance. This creates a window of just over 4 months during which it was expected that software would become patent eligible.

As a consequence of the rejection of the ordinance, ambiguity persisted in the granting practice of the Indian patent office (IPO) until June 2005 when the granting practice with regard to software patents was clarified in a set of guidelines ${ }^{2}$ The chronology of all the events described is summarized in Figure 1.

Figure 1: Chronology of patentability of software de jure and de facto

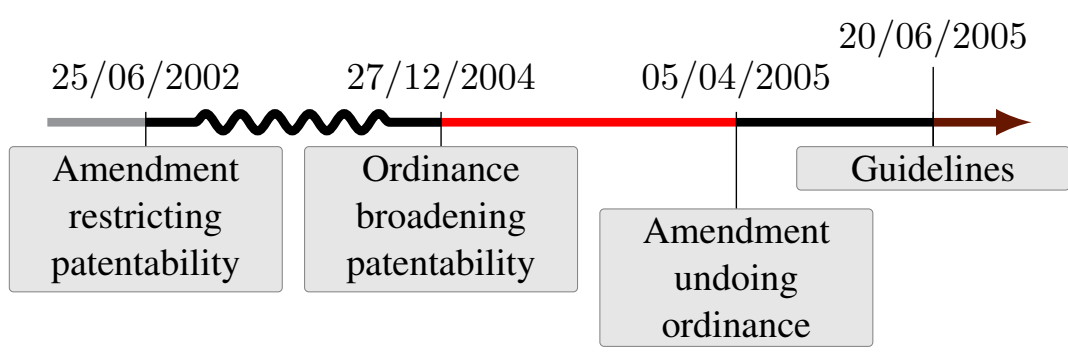

Notes: Red color indicates softening of restrictions on software patentability. Black color indicates a tightening of restrictions on software patentability.

\section{Data}

To analyze the effects of changes in the availability of patent protection on software in India, we construct a firm-level dataset by matching domestic and USPTO patent filings (see online Appendix A of all 294 publicly traded software companies registered in India to data on these firms from the PROWESS database (Center for Monitoring of the Indian Economy) for the period 2000-2007.

\section{Results}

\subsection{Patent Filings}

Figure 2 shows total patent filings of publicly traded software companies in India by quarter over the entire 2000-2007 period ${ }^{3}$ The graph shows that the absolute number of filings by Indian

\footnotetext{
${ }^{2}$ The IPO established that "claims relating to software program product [sic] are nothing but computer program per se simply expressed on a computer readable storage medium and as such are not allowable" (Manual of Patent Practice and Procedure 2005, Annexure II 7.3).

${ }^{3}$ Although there is no official definition of software patents, we manually check all patent filings to ensure they cover software inventions
} 
software companies at both the Indian and the U.S. patent offices is very modest. That said, a total of 217 patent filings with the IPO and an overall share of 9\% of patenting companies among all listed software companies is still substantial, keeping in mind that software in principle remained unpatentable throughout the period studied.

Figure 2: Total patent filings - IPO vs USPTO, 2000-2007

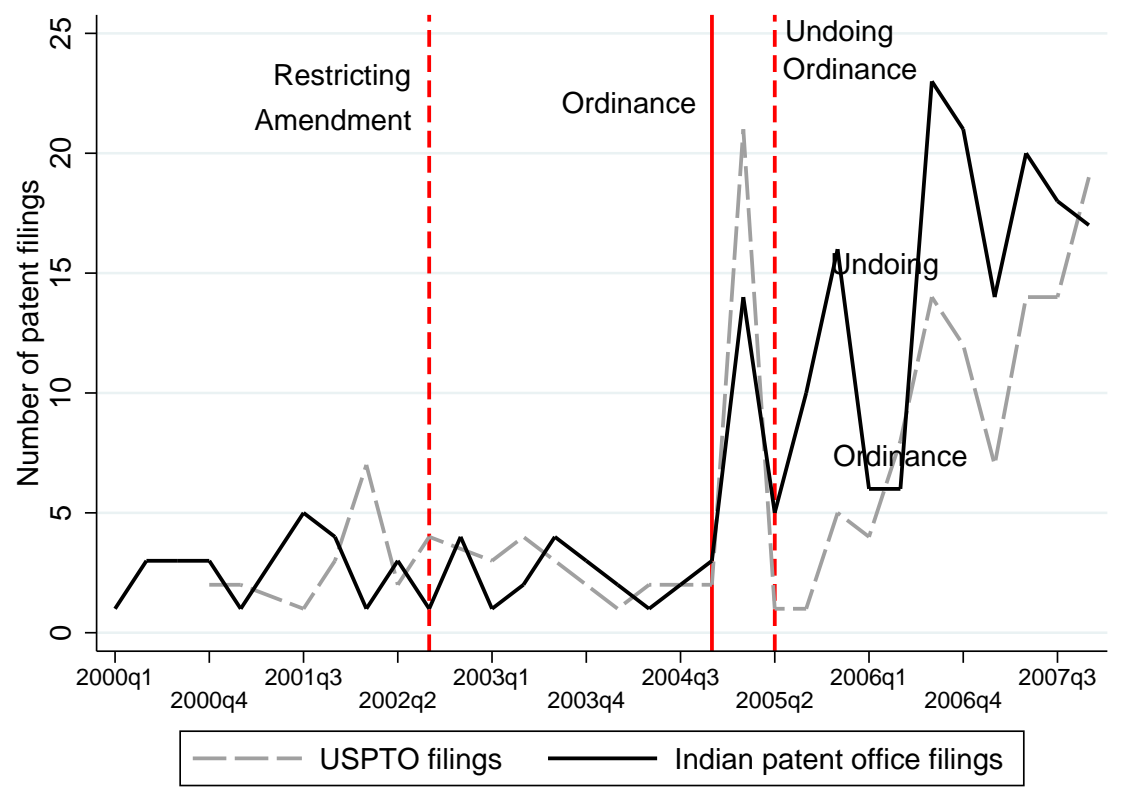

While Figure 2 indicates that despite the restrictions placed on patentability software companies have been filing software-related patent applications, Figure A-2 in the online appendix indicates that very few of these filings with the IPO were granted: only $14.5 \%$. Perhaps even more revealing, the only patent applications officially rejected by the IPO are applications filed immediately after the announcement of the 2004 ordinance. For comparison, until the end of 2004 all filings at the USPTO were granted ${ }^{4}$ The substantially larger grant rate at the USPTO underscores the restrictive approach adopted by the IPO and shows that despite a relatively large number of software patent filings at the IPO, hardly any software patents were granted. This suggests that the Ordinance would have had an important impact on patent granting practices.

\subsection{Event Study}

Next, we analyze stock market reactions to the (proposed) policy changes for the entire set of software companies in our data: if including software in patentable subject matter is privately beneficial to firms, we would expect the softening (tightening) of restrictions on software patentability to have a positive (negative) effect on firm valuation. Figure 3 provides a graphical representation of the Cumulative Abnormal Returns (CAR) computed over the 11-day event window adopting the Constant Mean Return Model ${ }^{5}$ In all graphs we indicate statistically significant (insignificant) average CAR across all listed software firms in India with a filled (hollow) marker, adopting a 5\% significance level.

\footnotetext{
${ }^{4}$ See Figure A-3 in the online Appendix. Note also that software patents continued to be patent-eligible in the U.S. throughout our period of analysis.

${ }^{5}$ See online appendix $B$ for more details on the approach.
} 
Average Effects: Counter-intuitively, the ordinance broadening patentability in late December 2004 as well as its undoing in April 2005 are both shown to have had a positive impact, while the second event in 2005, the publication of the draft Manual of Patent Practice and Procedure with detailed guidelines to clarify the stance of the IPO represents a substantial negative shock. The estimates presented in Table 1 suggest that the broadening of the ordinance results in an average CAR of around $14 \%$, while its undoing led to a $10 \%$ average excess return. The drop in returns following the publication of the draft guidelines in June 2005 was of similar magnitude.

Heterogenous Effects: However, these averages are somewhat misleading and additional investigation reveals a more intricate yet consistent pattern across events: although the ordinance in 2004 and its undoing in April 2005 both had an average positive effect, this average in each case was driven by different firms. In contrast, the positive reaction to the ordinance in 2004 and and the drop in average CAR in June 2005 were driven by the same firms.

In order to illustrate this matter empirically we plot firm-specific CAR at time $t+5$ following each event in Figure $4^{6}$ in the upper panel we observe that many firms with high CAR in 2004 saw this measure drop in April 2005 (blue downward arrows) and that the average positive CAR - indicated by the dashed horizontal line - is driven by other firms with low CAR for the December 2004 event (red upward arrows). From this we conclude that the identity of the firms which drove the average positive CAR in either time period differed. Turning to the lower panel of the same Figure, we observe a multitude of long blue arrows: firms with high CAR following the broadening of patentability in 2004 saw their CAR drop to zero or negative values when the June 2005 guidelines firmly shut the door on software patentability. This significant drop is driving the average negative CAR in the sample - indicated by the dashed horizontal line - whereas firms with comparatively low or negative CAR in 2004 (red arrows) now represent only a limited positive counterweight. We conclude for the lower panel that the average CAR in both periods was primarily driven by the same firms, namely those which were deemed by the market to benefit from a broadening of patentability.

To explore the heterogeneity further, we use a difference-in-differences approach where we distinguish between firms that had at least one patent before the first policy change (ordinance) and those that did not. We find that the market reacted positively to the ordinance in 2004 for patenting firms (see online appendix Table A-1), consistent with the idea that these firms were expected to patent more in the future (an intensive margin effect) and increase in value. We see a negative effect for patenting firms as a result of the undoing of the ordinance, which is also consistent with this argument.

Next, given that we have detected differential groups within our sample, we ask whether specific observable company characteristics can explain the substantial heterogeneity across firms associated with the policy changes illustrated in Figure 4. As dependent variable we construct a dummy variable $I_{\text {drop }}$ equal to unity (a) if the firm-specific CAR at $t+5$ following the April 2005 undoing of the ordinance is smaller than that $t+5$ following the December 2004 event, and (b) if the firm-specific CAR at $t+5$ for the June 2005 revised guidelines is smaller than its equivalent for the December 2004 ordinance broadening patentability - in terms of the plots in Figure 4 we are trying to predict the blue arrows. An alternative dependent variable ' $\triangle C A R$ ' measures the magnitude of change in CAR (in either case 2005 less 2004 event), whereby a large positive (negative) value suggests a significant rise (drop) in relative CAR between the two events.

As firm-level characteristics, we use data on sales, firm age, share of services in total sales

\footnotetext{
${ }^{6}$ In both panels ' + ' and ' $x$ ' indicate firms which only had one CAR estimate, in the former case for the respective 2005 event, in the latter for 2004.
} 
Figure 3: CAR for Constant Mean Models
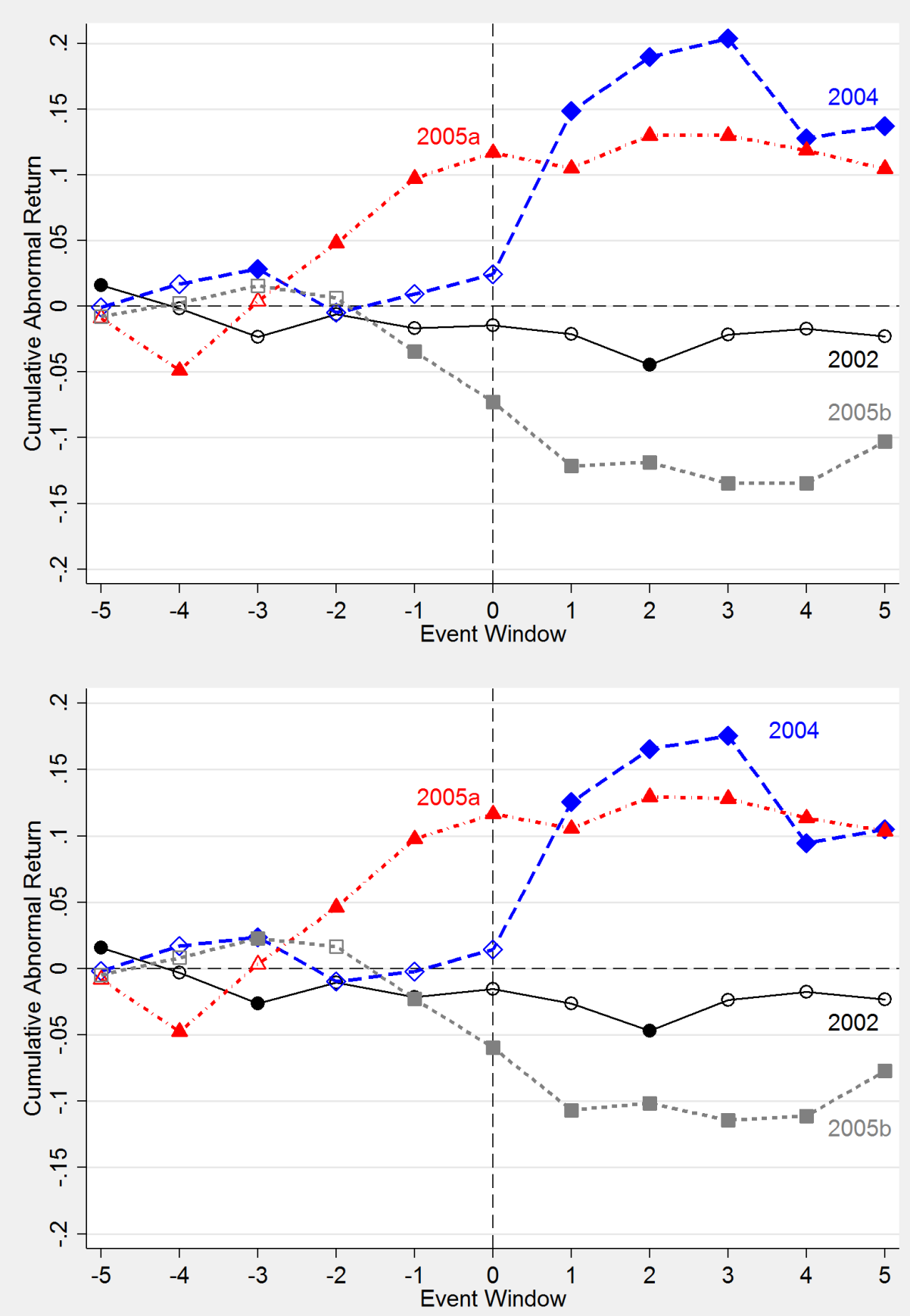

Notes: The event analysis in the upper panel adopts a 50-day estimation window (minimum number of observations: 30) while the lower panel adopts a 70-day one (minimum observations: 50). Within each plot the series markers indicate statistically insignificant (hollow marker) and significant (filled marker) $\mathrm{CAR}_{\tau}$ where we adopt a $5 \%$ level of significance. The CAR in Table 1 below report the estimates at $t+5$. 
Table 1: Cumulative Abnormal Return Estimates (Mean, Market Models)

\begin{tabular}{|c|c|c|c|c|c|}
\hline \multirow[t]{2}{*}{ Date } & \multirow[t]{2}{*}{ Event } & \multicolumn{2}{|c|}{ Mean Return Model } & \multicolumn{2}{|c|}{ Market Return Model } \\
\hline & & $\mathrm{CAR}[-5,+5]$ & abs SE & $\operatorname{CAR}[-5,+5]$ & abs SE \\
\hline June 252002 & $\begin{array}{l}\text { Amendment restricting } \\
\text { patentability }\end{array}$ & -0.0227 & {$[0.0194]$} & -0.0226 & {$[0.0193]$} \\
\hline December 272004 & $\begin{array}{l}\text { Ordinance broadening } \\
\text { patentability }\end{array}$ & 0.1371 & {$[0.0272]^{* * *}$} & 0.1429 & {$[0.0279]^{* * *}$} \\
\hline April 52005 & $\begin{array}{l}\text { Amendment undoing or- } \\
\text { dinance }\end{array}$ & 0.1048 & {$[0.0201]^{* * *}$} & 0.1067 & {$[0.0201]^{* * *}$} \\
\hline June 202005 & Revised guidelines & -0.1029 & {$[0.0212]^{* * *}$} & -0.1320 & {$[0.0219]^{* * *}$} \\
\hline
\end{tabular}

Notes: The market return model estimation adopts the BSE Index; results for alternative indices are qualitatively identical. * $p<0.10, * * p<0.05, * * * p<0.01$.

Table 2: Which firms where most affected by the policy changes?

April 2005 \& June 2005 vs December 2004

\begin{tabular}{|c|c|c|c|c|c|c|c|c|}
\hline & \multicolumn{4}{|c|}{ April 2005 vs December 2004} & \multicolumn{4}{|c|}{ June 2005 vs December 2004} \\
\hline & {$[1]$} & {$[2]$} & [3] & [4] & {$[5]$} & [6] & [7] & {$[8]$} \\
\hline & $I_{\mathrm{drop}}$ & $I_{\mathrm{drop}}$ & $\triangle C A R$ & $\triangle C A R$ & $I_{\mathrm{drop}}$ & $I_{\mathrm{drop}}$ & $\triangle C A R$ & $\triangle C A R$ \\
\hline ln Sales & $\begin{array}{c}-0.057 \\
{[0.027]^{* *}}\end{array}$ & $\begin{array}{c}-0.072 \\
{[0.023]^{* * *}}\end{array}$ & $\begin{array}{c}0.045 \\
{[0.016] * * *}\end{array}$ & $\begin{array}{c}0.056 \\
{[0.015]^{* * *}}\end{array}$ & $\begin{array}{c}-0.038 \\
{[0.024]}\end{array}$ & $\begin{array}{c}-0.035 \\
{[0.024]}\end{array}$ & $\begin{array}{c}0.058 \\
{[0.024]^{* *}}\end{array}$ & $\begin{array}{c}0.060 \\
{[0.025]^{* *}}\end{array}$ \\
\hline Firm Age & $\begin{array}{c}-0.004 \\
{[0.011]}\end{array}$ & $\begin{array}{c}0.000 \\
{[0.012]}\end{array}$ & $\begin{array}{c}0.001 \\
{[0.007]}\end{array}$ & $\begin{array}{c}0.000 \\
{[0.007]}\end{array}$ & $\begin{array}{c}0.002 \\
{[0.011]}\end{array}$ & $\begin{array}{c}0.001 \\
{[0.012]}\end{array}$ & $\begin{array}{c}0.003 \\
{[0.006]}\end{array}$ & $\begin{array}{c}0.002 \\
{[0.007]}\end{array}$ \\
\hline Service Share & $\begin{array}{l}-0.054 \\
{[0.147]}\end{array}$ & $\begin{array}{c}-0.043 \\
{[0.138]}\end{array}$ & $\begin{array}{c}0.164 \\
{[0.092]^{*}}\end{array}$ & $\begin{array}{c}0.154 \\
{[0.089]^{*}}\end{array}$ & $\begin{array}{c}0.151 \\
{[0.142]}\end{array}$ & $\begin{array}{c}0.142 \\
{[0.142]}\end{array}$ & $\begin{array}{c}-0.013 \\
{[0.120]}\end{array}$ & $\begin{array}{c}-0.014 \\
{[0.120]}\end{array}$ \\
\hline$I_{\mathrm{R} \& \mathrm{D}}$ & $\begin{array}{c}-0.254 \\
{[0.351]}\end{array}$ & $\begin{array}{c}-0.165 \\
{[0.347]}\end{array}$ & $\begin{array}{c}0.214 \\
{[0.350]}\end{array}$ & $\begin{array}{c}0.202 \\
{[0.373]}\end{array}$ & $\begin{array}{c}-0.213 \\
{[0.278]}\end{array}$ & $\begin{array}{c}-0.169 \\
{[0.276]}\end{array}$ & $\begin{array}{c}0.038 \\
{[0.184]}\end{array}$ & $\begin{array}{c}0.038 \\
{[0.184]}\end{array}$ \\
\hline$I_{\text {Patents }}$ & $\begin{array}{c}0.288 \\
{[0.209]}\end{array}$ & & $\begin{array}{c}-0.006 \\
{[0.146]}\end{array}$ & & $\begin{array}{c}0.133 \\
{[0.159]}\end{array}$ & & $\begin{array}{l}-0.076 \\
{[0.104]}\end{array}$ & \\
\hline$\sum$ US patents & & $\begin{array}{c}0.003 \\
{[0.022]}\end{array}$ & & $\begin{array}{c}0.003 \\
{[0.019]}\end{array}$ & & $\begin{array}{c}-0.017 \\
{[0.035]}\end{array}$ & & $\begin{array}{c}0.001 \\
{[0.013]}\end{array}$ \\
\hline$\sum$ Indian patents & & $\begin{array}{c}0.051 \\
{[0.014]^{* * *}}\end{array}$ & & $\begin{array}{c}-0.018 \\
{[0.008]^{* *}}\end{array}$ & & $\begin{array}{c}0.019 \\
{[0.023]}\end{array}$ & & $\begin{array}{c}-0.013 \\
{[0.008]^{*}}\end{array}$ \\
\hline Constant & $\begin{array}{c}0.740 \\
{[0.257]^{* * *}}\end{array}$ & $\begin{array}{c}0.743 \\
{[0.255]^{* * * *}}\end{array}$ & $\begin{array}{c}-0.338 \\
{[0.147]^{* *}}\end{array}$ & $\begin{array}{c}-0.360 \\
{[0.155]^{* *}}\end{array}$ & $\begin{array}{c}0.62 \\
{[0.219]^{* * *}}\end{array}$ & $\begin{array}{c}0.639 \\
{[0.219]^{* * *}}\end{array}$ & $\begin{array}{c}-0.473 \\
{[0.195]^{* *}}\end{array}$ & $\begin{array}{c}-0.484 \\
{[0.198]^{* *}}\end{array}$ \\
\hline Number of firms & 91 & 91 & 91 & 91 & 104 & 104 & 104 & 104 \\
\hline R-squared & 0.20 & 0.27 & 0.21 & 0.23 & 0.09 & 0.09 & 0.21 & 0.21 \\
\hline $\begin{array}{l}\text { Notes: The sample of firn } \\
\text { upper plot of Figure } 4 \text { Th } \\
\text { arrows in the lower plot o } \\
\text { following the } 2005 \text { event } \\
\text { [8] the dependent variable } \\
\text { (decrease) in CAR. Some } \\
(n=8 \& n=10 \text { for [ } \\
\text { includes also dummies for } \\
\text { significance at the } 10 \%, 5\end{array}$ & $\begin{array}{l}\text { nalysed }(n= \\
\text { mple of firms } \\
\text { gure 4 The de } \\
\text { ril in [1] and [2 } \\
\text { he magnitude } \\
\text { he variables ar } \\
8] \text { and [1]-[4] r } \\
\text { ssing observati } \\
\text { nd } 1 \% \text { level us }\end{array}$ & $\begin{array}{l}\text { in columns } \\
\text { sed }(n= \\
\text { ent variable } \\
\text { ne in [5] an } \\
\text { ference bet } \\
\text { icators for } \\
\text { ctively), wh } \\
\text { elated to sa } \\
* * \text { and ** }\end{array}$ & $\begin{array}{l}\text { was smalle } \\
\text { hese two C } \\
\text { nall groups } \\
\text { ve U.S. pat } \\
=3 \& n \\
\text { ectively. }\end{array}$ & $\begin{array}{l}\text { that } t+5 \\
\text { (both times } \\
n=3 \text { which carr }\end{array}$ & $\begin{array}{l}\text { events and } \\
\text { th CAR for } \\
\text { 6] is a dumn } \\
\text { the Decem } \\
\text { 2004): larg } \\
\text { ne R\&D ( } n \\
\text { nd which ha }\end{array}$ & $\begin{array}{l}\text { tical to that } \\
\text { ents and is } \\
\text { hose firms } \\
4 \text { event. In } \\
\text { ve (negative } \\
n=7 \mathrm{fir} \\
\text { ian patents }\end{array}$ & $\begin{array}{l}\text { he blue and } \\
\text { ical to that } \\
\text { hich their } \\
\text { LS regress } \\
\text { lues indicat } \\
\text { which hav } \\
=7 \& n=\end{array}$ & $\begin{array}{l}\text { arrows in the } \\
\text { he blue and red } \\
\text { at } t+5 \\
\text { in [3], [4], [7] and } \\
\text { ignificant increase } \\
\text { ne patent(s) } \\
\text { Each model } \\
\text { tatistical }\end{array}$ \\
\hline
\end{tabular}


Figure 4: $\mathrm{CAR}_{t+5}$ by firm, comparing 2004 and 2005 events
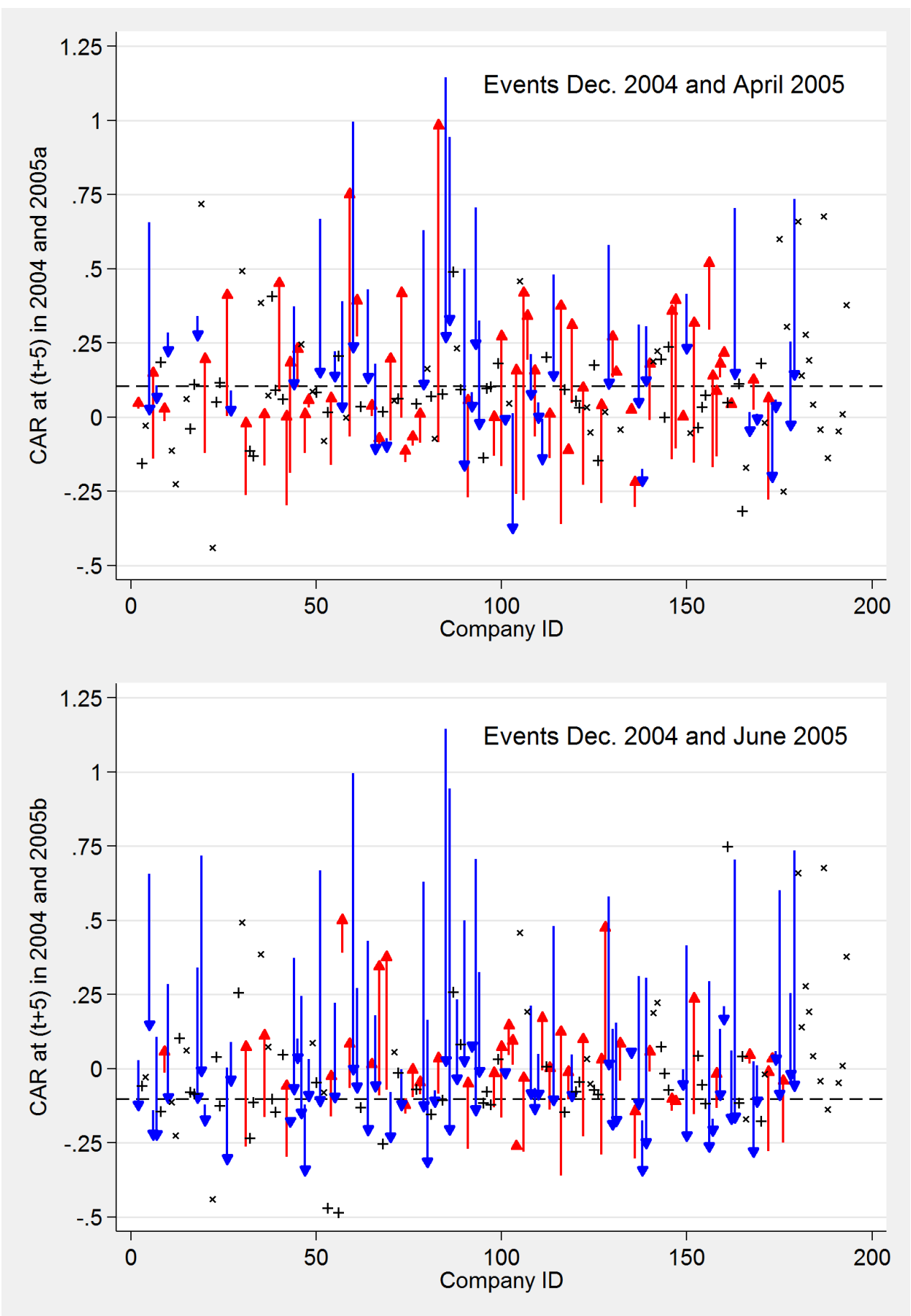

Notes: The two graphs compare the firm-specific CARs for the broadening of patentability in December 2004 and its subsequent undoing in April 2005 (event 2005a) - upper plot - as well as the CARs for the 2004 event and the revised guidelines in June 2005 (event 2005b). Firms are ordered by id along the $x$-axis - this merely acts to provide a visual ranking of the firms. The red and blue arrows indicate the difference in firm-specific CAR 5 days after the respective event: for red (blue) arrows firm-specific CAR in 2005 (2004) exceeds that in 2004 (2005). Two symbols indicate firms where one or the other CAR is missing: '+' are values for the respective 2005 event (i.e. 2004 is missing), ' $x$ ' are values for 2004 (i.e. 2005 event observation is missing). The horizontal lines indicate average sample CAR for event 2005a and 2005b in the upper and lower panel, respectively. 
and innovation-related information ( $R \& D$ expenditure dummy, patent dummy, separate patent counts for USPTO and the IPO). Since the various events occur within less than six months and our dependent variables are akin to time differences we only use the 2004 information on firm characteristics in these regressions $7^{7}$ Table 2 presents our results (for the corresponding descriptive statistics see Table A-2 in the online appendix): columns [1], [2], [5], and [6] adopt a linear probability model (LPM) to predict the $I_{\text {drop dummy }}{ }^{8}$ columns [3], [4], [7], and [8] estimate a least squares model for the ' $\triangle C A R$ ' variable (these models equate to predicting the length and signs of all arrows in Figure 4 ).

Our regressions $9^{9}$ indicate that larger firms (in terms of sales volume) ceteris paribus were less significantly affected by the two events tightening patentability. The coefficients on sales are also negative in columns [5] and [6] (the drop in CAR between the December 2004 and June 2005 events) but not statistically significantly different from zero. Firm age or services share ${ }^{10}$ are not consistently correlated with a drop in CAR or the change in CAR. The coefficients on patent filings at the IPO suggest companies that filed for patents before the 2004-2005 sequence of policy shocks were more likely to see a drop in market returns when the ordinance was undone and when the revised guidelines were issued.

\section{Conclusion}

We study the effect of unanticipated proposed changes in the patent law and regulations that affected the patentability of software on all publicly listed software companies in India. Our analysis of market returns shows some clear patterns highlighting the positive market response to a softening of patenting restrictions in December 2004 and a negative response once these restrictions were reinforced in June 2005. We further showed that the market indicated a heterogeneous response to the former event, which explains the counter-intuitive positive average market response to the undoing of the ordinance in April 2004. That is, companies that did not experience positive returns when the ordinance was announced experienced positive returns when it was undone. In contrast, the negative effect of the tightening of patenting restrictions through the revised guidelines on those software companies that had experienced positive returns when the ordinance was announced drowned out the more modest positive reaction by the other companies. Investigation of the characteristics of firms reveals that comparatively smaller software companies were most adversely affected by the tightening of patentability.

\section{Acknowledgements}

We thank Luis Aguiar, Brian Love, and participants at the 12th ZEW Economics of ICT Conference and the 8th Conference on Micro Evidence on Innovation and Development in Delhi for helpful comments. We are grateful to Rubina Anjum for excellent research assistance with the data collection. Financial support from the LABEX ECODEC (ANR-11-IDEX-0003/Labex Ecodec/ANR-11-LABX-0047) is gratefully acknowledged.

\footnotetext{
${ }^{7}$ Our results are qualitatively identical if we adopt the 2005 information instead.

${ }^{8}$ A nonlinear model (logit) yields qualitatively identical results. For bootstrap standard errors see Table A-3 in the online appendix.

${ }^{9}$ It should be borne in mind that the sample size (columns [1]-[4]: $n=91$, columns [5]-[8]: $n=104$ ) is moderate, and that the innovation indicators identify only a small subset of these firms.

${ }^{10}$ This measure is fairly concentrated: $15 \%$ of firms for which we have this information have zero share of services in total sales, while around $7 \%$ have between $2 \%$ and $90 \%$, leaving $78 \%$ with virtually no product-related sales.
} 


\section{References}

Arora, A., L. Branstetter, And C. Chatterjee (2011): "Strong Medicine: Patent Reform \& the emergence of a Research-Driven Pharmaceutical Industry in India," in The Location of Biopharmaceutical Activity, ed. by C. I. M. and M. J. Slaughter, NBER.

Arora, A., L. Branstetter, C. Chatterjee, And K. Saggi (2009): "Strong Medicine? Patent Reform and the Transformation of the Indian Pharmaceutical Industry," mimeo.

Chen, Y. and T. Puttitanum (2005): "Intellectual Property Rights and Innovation in Developing Countries," Journal of Development Economics, 78, 474-493.

Grossman, G. M. AND E. L.-C. LAi (2004): "International Protection of Intellectual Property," American Economic Review, 95, 1635-1653.

Helpman, E. (1993): "Innovation, Imitation, and Intellectual Property Rights," Econometrica, $61,1247-1280$.

Hu, A. AND I. PNG (2013): "Patent rights and economic growth: Evidence from cross-country panels of manufacturing industries," Oxford Economic Papers, 65, 675-698.

Hu, G. A. AND G. JEFFERSON (2009): "A great wall of patents: What is behind China's recent patent explosion?" Journal of Development Economics, 90, 57-68.

JAFFe, A. AND J. LeRner (2004): Innovation and Its Discontents: How Our Broken Patent System is Endangering Innovation and Progress, and What to Do About It.

KANWAR, S. AND R. EvENSON (2003): "Does intellectual property protection spur technical change?" Oxford Economic Papers, 55, 235-264.

Kyle, M. AND Y. Qian (2013): "Intellectual Property Rights and Access to Innovation: Evidence from TRIPS," mimeo.

Lerner, J. (2002): “150 Years of Patent Protection,” American Economic Review, 92, 221225.

Nordhaus, W. D. (1969): Invention, Growth, and Welfare: A Theoretical Treatment of Technological Change, MIT Press.

Penrose, E. (1973): "International Patenting and the Less-Developed Countries," The Economic Journal, 83, 768-786.

QIAN, Y. (2007): "Do additional national patent laws stimulate domestic innovation in a global patenting environment: A cross-country analysis of pharmaceutical patent protection, 19782002," Review of Economics and Statistics, 89, 436-453.

SAKAKIBARA, M. AND L. BRANSTETTER (2001): "Do stronger patents induce more innovation? Evidence from the 1988 Japanese patent law reforms," RAND Journal of Economics, $32,77-100$

SAMPAT, B. (2010): "Institutional Innovation or Institutional Imitation? The Impacts of TRIPs on India's Patent Law and Practice," mimeo. 
SCHERER, F. AND S. Weisburst (1995): "Economic Effects of Strengthening Pharmaceutical Patent Protection in Italy," International Review of Industrial Property and Copyright Law, 26, 1009-1024.

UNCTAD (2012): Information Economy Report 2012: The Software Industry and Developing Countries, United Nations Conference for Trade and Development. 


\section{Online Appendix — not intended for publication}

\section{A Firm-level and Patent Data}

For international patent filings with the U.S. Patent and Trademark Office (USPTO) we rely on EPO's PATSTAT database. We extract data on patent filings from PATSTAT patents filed by Indian residents at the USPTO. While the USPTO data can be expected to be complete, there is serious under-reporting in PATSTAT of Indian domestic patent filings with the Indian Patent Office (IPO). We therefore rely instead on three other databases. The electronic patent search facility available on IPO's website iPairs provides information on published patents only from 2005 onwards ${ }^{11}$ For patent filings before 2005, we rely on the EKASWA database assembled by the Patent Facilitating Centre (PFC) of the Indian Department of Science and Technology. EKASWA contains all domestic patents published between January 1995 and early 2005 ${ }^{12}$ In addition, we complement the official data sources using the online portal BigPatents India.

The U.S. and Indian patent data are matched to the firm-level PROWESS database provided by the Center for Monitoring of the Indian Economy (CMIE). We focus on all software companies listed in India - both on the Bombay Stock Exchange (BSE) and the National Stock Exchange (NSE); a total of 294 software companies. For each firm in our dataset, we obtain detailed information on accounting balance sheets, financial statements, industry information, and share prices.

Due to the absence of a unique identifier shared by the firm-level and patent data, the main problem in constructing our dataset consists in matching patents to firms. To match assignee names to company names, we rely on a combination of an automated matching algorithm and extensive manual checking of the (un)matched data.

\section{B Event Study Methdology}

We use an event study approach looking at changes in companies' market valuation, which acts as a proxy for firm performance. The objective is to distinguish market reactions due to normal factors from reactions induced by the policy shocks. To do this, we specify a market model ('normal returns') and estimate deviations ('abnormal returns') from such a model over the event window. To illustrate, consider the event timeline in Figure A-1 where $\tau$ is the event date (policy shock):

Figure A-1: Event timeline

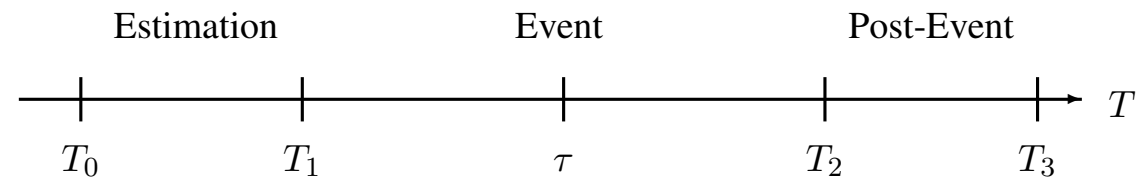

The market model specifies the relationship between the period $t$ return on security $i\left(r_{i t}\right)$ and the period $t$ return on the market portfolio $\left(r_{t}^{m}\right)$ :

\footnotetext{
${ }^{11}$ The search facility also provides information on granted patents before 2005 . This, however, misses any patent that was not granted. Given our research objective, we are interested in any patent filing independently of whether it was eventually granted.

${ }^{12}$ The data in EKASWA come from the Patent Office Gazette, which was published only in print format. The Gazette was replaced in 2005 by the Patent Journal, which is published both in print and electronic formats.
} 


$$
r_{i t}=\alpha+\beta r_{t}^{m}+\epsilon_{i t}
$$

We estimate this market model in the estimation window $\left(T_{0}-T_{1}\right)$ prior to the event $\tau$ to obtain estimates for $\alpha, \beta$. Using these estimated parameters we predict expected return $\hat{r}_{i t}^{p}$ in the event window $\left(T_{1}-T_{2}\right)$, from which in turn we can then compute the deviation from the observed return, thus providing a measure of 'abnormal returns' $\left(\hat{\epsilon}_{i t}\right)$ :

$$
\hat{\epsilon}_{i t}=r_{i t}-\hat{r}_{i t}^{p} \quad \hat{r}_{i t}^{p}=\hat{\alpha}+\hat{\beta} r_{t}^{m}
$$

The cumulative abnormal return (CAR) over the event window is then simply the accumulated $\hat{\epsilon}_{i t}$ from $T_{1}$ to $T_{2}$ :

$$
C A R_{i t}=\sum_{\tau=T_{1}}^{T_{2}} \hat{\epsilon}_{i t}
$$

If the event had no effect on our subset of firms then $\hat{\epsilon}_{i t}$ should have mean 0 . If the policy change had a positive effect then we observe abnormal returns, $\hat{\epsilon}_{i t}>0$ which produce an upward sloping CAR. The underlying assumption is that without the event or singular information, the relation between a firm's asset return and the market return is stable. We present our results as average CAR estimates across all software firms, reporting the outcome at $t+5$ days as well as (in graphical form) for days $t-5$ to $t+5$ : while the latter will indicate any response to the specific event, the former will concentrate on the likely permanence of the impact. Note also that we specify a pre-event window from $t-80$ to $t-10$ days, which provides substantial time series observations to estimate the expected returns for firm $i$ while at the same time preventing any overlap between pre-event window for event $\tau$ and the event window for event $\tau-1$. The event window encompasses the 11 days from $t-5$ to $t+5$. Both of these choices are fairly standard in the literature and we verified that reasonable changes to these window sizes do not affect our results in any significant manner. Finally, we also investigate a number of alternatives for the market model outlined above: firstly, we analyze a simpler 'constant mean return' model, where the abnormal returns are computed for firm $i$ without accounting for the return on the market portfolio, i.e. $r_{t}^{m}$ is dropped from equation (1). Secondly, in the standard 'market return model' we investigate a number of alternative indices for market return, namely the BSE Sensex, the CMIE Index for IT, the BSE Tech Index and the CNX IT Sector Index of the National Stock Exchange of India. All additional results are available on request. 


\section{Additional Figures}

Figure A-2: Legal status of patent filings at the Indian Patent Office - 2000-2007

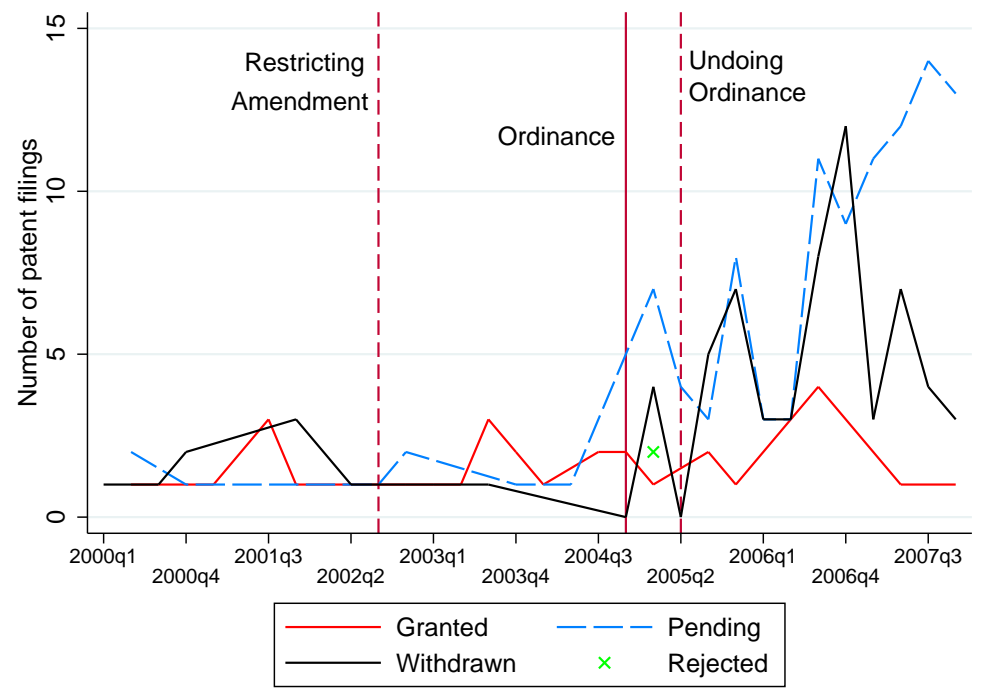

Notes: The legal status was obtained from the iPairs website of the Indian Patent Office in February 2014.

Figure A-3: Legal status of patent filings at the USPTO - 2000-2007

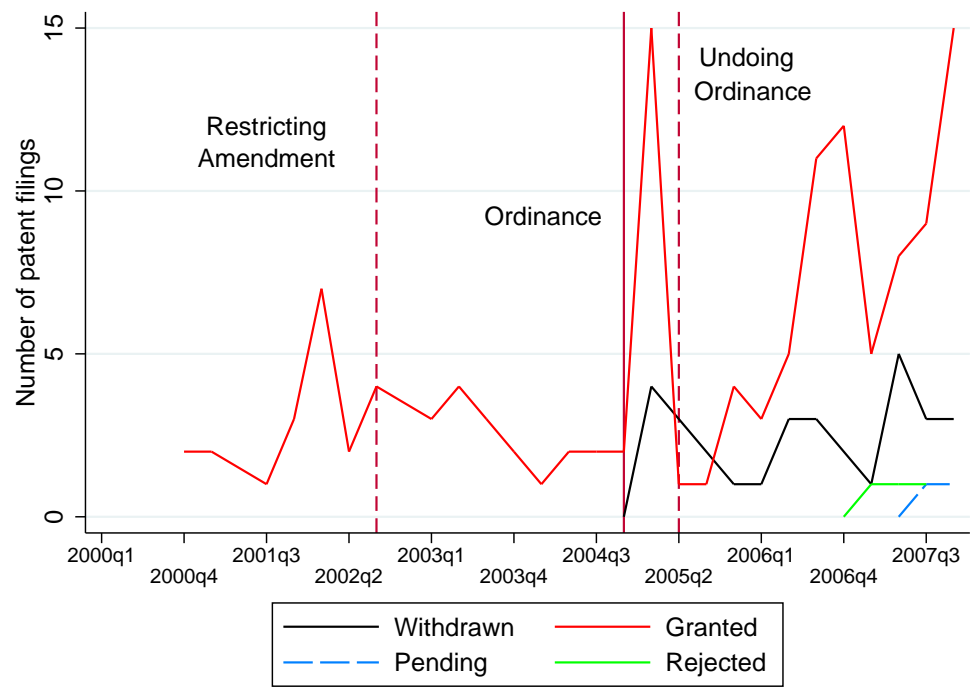

Notes: The legal status was obtained from the PAIR website of the USPTO in February 2014. 


\section{Additional Tables}

Table A-1: DID Estimates

\begin{tabular}{|c|c|c|c|c|c|c|}
\hline & \multicolumn{3}{|c|}{ Daily Data } & \multicolumn{3}{|c|}{ Pre-Post Data } \\
\hline & 2004 & $2005 \mathrm{a}$ & $2005 b$ & 2004 & $2005 \mathrm{a}$ & $2005 b$ \\
\hline Post & $\begin{array}{c}-0.004^{* * *} \\
(0.001)\end{array}$ & $\begin{array}{c}0.005^{* * *} \\
(0.001)\end{array}$ & $\begin{array}{c}-0.005^{* * *} \\
(0.001)\end{array}$ & $\begin{array}{c}-0.008^{* * *} \\
(0.002)\end{array}$ & $\begin{array}{c}0.006^{* * *} \\
(0.002)\end{array}$ & $\begin{array}{c}-0.006^{* * *} \\
(0.002)\end{array}$ \\
\hline Post $\times$ Treat & $\begin{array}{l}0.004^{* *} \\
(0.002)\end{array}$ & $\begin{array}{c}-0.004^{* *} \\
(0.002)\end{array}$ & $\begin{array}{c}0.006^{* * *} \\
(0.001)\end{array}$ & $\begin{array}{l}0.014^{* *} \\
(0.007)\end{array}$ & $\begin{array}{c}-0.005^{*} \\
(0.002)\end{array}$ & $\begin{array}{c}0.007^{* * *} \\
(0.002)\end{array}$ \\
\hline Observations & 28,999 & 25,882 & 31,606 & 324 & 328 & 332 \\
\hline
\end{tabular}

Table A-2: Descriptive Statistics for Regression sample in Table 2

\begin{tabular}{|c|c|c|c|c|c|c|c|c|c|c|c|c|}
\hline \multirow[b]{2}{*}{ variable } & \multicolumn{6}{|c|}{ Panel A: April 2005 vs December 2004} & \multicolumn{6}{|c|}{ Panel B: June 2005 vs December 2004} \\
\hline & $\mathrm{N}$ & mean & median & sd & $\min$ & $\max$ & $\mathrm{N}$ & mean & median & sd & $\min$ & $\max$ \\
\hline$I_{\text {drop }}$ & 91 & 0.42 & 0 & & 0 & 1 & 104 & 0.63 & 1 & & 0 & 1 \\
\hline$\triangle C A R$ & 91 & 0.03 & 0.04 & 0.37 & -0.89 & 1.09 & 104 & -0.18 & -0.12 & 0.41 & -1.93 & 0.51 \\
\hline In Sales & 91 & 5.16 & 5.18 & 2.48 & 0 & 11.63 & 104 & 5.17 & 5.16 & 2.62 & 0 & 11.63 \\
\hline Firm Age & 91 & 14.33 & 14.00 & 6.05 & 0 & 30 & 104 & 14.38 & 14.00 & 6.00 & 0 & 30 \\
\hline Service share & 91 & 0.74 & 1.00 & 0.42 & 0 & 1 & 104 & 0.76 & 1.00 & 0.42 & 0 & 1 \\
\hline$I_{\mathrm{R} \& \mathrm{D}}$ & 91 & 0.04 & 0 & & 0 & 1 & 104 & 0.05 & 0 & & 0 & 1 \\
\hline$I_{\text {Patents }}$ & 91 & 0.13 & 0 & & 0 & 1 & 104 & 0.15 & 0 & & 0 & 1 \\
\hline$\sum$ US patents & 91 & 0.38 & 0 & 2.05 & 0 & 13 & 104 & 0.39 & 0 & 1.958 & 0 & 13 \\
\hline$\sum$ US patents & 91 & 0.71 & 0 & 3.31 & 0 & 27 & 104 & 0.79 & 0 & 3.404 & 0 & 27 \\
\hline Missing sales & 91 & 0.04 & 0 & & 0 & 1 & 104 & 0.05 & 0 & & 0 & 1 \\
\hline Missing age & 91 & 0.05 & 0 & & 0 & 1 & 104 & 0.05 & 0 & & 0 & 1 \\
\hline Missing Service share & 91 & 0.08 & 0 & & 0 & 1 & 104 & 0.07 & 0 & & 0 & 1 \\
\hline
\end{tabular}

Notes: The sample of firms analysed ( $n=91$ ) in Panel A includes all those with CAR for both events and is identical to that for the blue and red arrows in the upper plot of Figure 4 in the main text. The sample of firms analysed $(n=104)$ in Panel B includes all those with CAR for both events and is identical to that for the blue and red arrows in the lower plot of the aforementioned Figure. The dependent variables in the LPM regressions of table X are (i) a dummy for those firms for which their CAR at $t+5$ following the 2005 event was smaller than that $t+5$ following the December 2004 event: $I_{\text {drop }}$; and (ii) the magnitude of difference between these two CARs (both times 2005 less 2004), $\triangle C A R$ : large positive (negative) values indicate a significant increase (decrease) in CAR. As is customary we do not report standard deviations for dummy variables. 
Table A-3: Which firms where most affected by the policy changes? April 2005 \& June 2005 vs December 2004

\begin{tabular}{|c|c|c|c|c|c|c|c|c|}
\hline & \multicolumn{4}{|c|}{ April 2005 vs December 2004} & \multicolumn{4}{|c|}{ June 2005 vs December 2004} \\
\hline & {$[1]$} & {$[2]$} & [3] & {$[4]$} & [5] & [6] & [7] & [8] \\
\hline & $I_{\text {drop }}$ & $I_{\text {drop }}$ & $\triangle C A R$ & $\triangle C A R$ & $I_{\mathrm{drop}}$ & $I_{\mathrm{drop}}$ & $\triangle C A R$ & $\triangle C A R$ \\
\hline ln Sales & $\begin{array}{c}-0.057 \\
{[0.027]^{*} *}\end{array}$ & $\begin{array}{c}-0.072 \\
{[0.022]^{* * *}}\end{array}$ & $\begin{array}{c}0.045 \\
{[0.018]^{* * *}}\end{array}$ & $\begin{array}{c}0.056 \\
{[0.014]^{* * *}}\end{array}$ & $\begin{array}{c}-0.038 \\
{[0.023]^{*}}\end{array}$ & $\begin{array}{c}-0.035 \\
{[0.025]}\end{array}$ & $\begin{array}{c}0.058 \\
{[0.029]^{* *}}\end{array}$ & $\begin{array}{c}0.060 \\
{[0.023]^{* * *}}\end{array}$ \\
\hline Firm Age & $\begin{array}{c}-0.004 \\
{[0.015]}\end{array}$ & $\begin{array}{c}0.000 \\
{[0.013]}\end{array}$ & $\begin{array}{c}0.001 \\
{[0.008]}\end{array}$ & $\begin{array}{c}0.000 \\
{[0.008]}\end{array}$ & $\begin{array}{c}0.002 \\
{[0.013]}\end{array}$ & $\begin{array}{c}0.001 \\
{[0.012]}\end{array}$ & $\begin{array}{c}0.003 \\
{[0.007]}\end{array}$ & $\begin{array}{c}0.002 \\
{[0.008]}\end{array}$ \\
\hline Service Share & $\begin{array}{c}-0.054 \\
{[0.147]}\end{array}$ & $\begin{array}{c}-0.043 \\
{[0.153]}\end{array}$ & $\begin{array}{c}0.164 \\
{[0.106]}\end{array}$ & $\begin{array}{c}0.154 \\
{[0.103]}\end{array}$ & $\begin{array}{c}0.151 \\
{[0.176]}\end{array}$ & $\begin{array}{c}0.142 \\
{[0.151]}\end{array}$ & $\begin{array}{c}-0.013 \\
{[0.121]}\end{array}$ & $\begin{array}{c}-0.014 \\
{[0.130]}\end{array}$ \\
\hline$I_{\mathrm{R} \& \mathrm{D}}$ & $\begin{array}{c}-0.254 \\
{[0.489]}\end{array}$ & $\begin{array}{c}-0.165 \\
{[0.470]}\end{array}$ & $\begin{array}{c}0.214 \\
{[0.374]}\end{array}$ & $\begin{array}{c}0.202 \\
{[0.499]}\end{array}$ & $\begin{array}{c}-0.213 \\
{[0.360]}\end{array}$ & $\begin{array}{c}-0.169 \\
{[0.380]}\end{array}$ & $\begin{array}{c}0.038 \\
{[0.178]}\end{array}$ & $\begin{array}{c}0.038 \\
{[0.226]}\end{array}$ \\
\hline$I_{\text {Patents }}$ & $\begin{array}{c}0.288 \\
{[0.266]}\end{array}$ & & $\begin{array}{c}-0.006 \\
{[0.158]}\end{array}$ & & $\begin{array}{c}0.133 \\
{[0.169]}\end{array}$ & & $\begin{array}{c}-0.076 \\
{[0.098]}\end{array}$ & \\
\hline$\sum$ US patents & & $\begin{array}{c}0.003 \\
{[0.167]}\end{array}$ & & $\begin{array}{c}0.003 \\
{[0.070]}\end{array}$ & & $\begin{array}{c}-0.017 \\
{[0.104]}\end{array}$ & & $\begin{array}{c}0.001 \\
{[0.031]}\end{array}$ \\
\hline$\sum$ Indian patents & & $\begin{array}{c}0.051 \\
{[0.055]}\end{array}$ & & $\begin{array}{c}-0.018 \\
{[0.040]}\end{array}$ & & $\begin{array}{c}0.019 \\
{[0.044]}\end{array}$ & & $\begin{array}{l}-0.013 \\
{[0.019]}\end{array}$ \\
\hline Constant & $\begin{array}{c}0.740 \\
{[0.291]^{* * *}}\end{array}$ & $\begin{array}{c}0.743 \\
{[0.334]^{* *}}\end{array}$ & $\begin{array}{c}-0.338 \\
{[0.154]^{* *}}\end{array}$ & $\begin{array}{c}-0.360 \\
{[0.189]^{*}}\end{array}$ & $\begin{array}{c}0.62 \\
{[0.273]^{* *}}\end{array}$ & $\begin{array}{c}0.639 \\
{[0.237]^{* * *}}\end{array}$ & $\begin{array}{c}-0.473 \\
{[0.225]^{* *}}\end{array}$ & $\begin{array}{c}-0.484 \\
{[0.185]^{* * *}}\end{array}$ \\
\hline Number of firms & 91 & 91 & 91 & 91 & 104 & 104 & 104 & 104 \\
\hline R-squared & 0.20 & 0.27 & 0.21 & 0.23 & 0.09 & 0.09 & 0.21 & 0.21 \\
\hline $\begin{array}{l}\text { Notes: The sample of firm } \\
\text { pper plot of Figure } 4 \text { Th } \\
\text { rrows in the lower plot of } \\
\text { ollowing the } 2005 \text { event } \\
\text { 8] the dependent variable } \\
\text { decrease) in CAR. Some } \\
n=8 \& n=10 \text { for [ } \\
\text { ncludes also dummies for } \\
\text { ignificance at the } 10 \%, 5\end{array}$ & $\begin{array}{l}\text { The de } \\
\text { in [1] and [ } \\
\text { e magnitude } \\
\text { variables a } \\
\text { and [1]-[4] } \\
\text { ing observat } \\
\text { d } 1 \% \text { level us }\end{array}$ & $\begin{array}{l}\text { ne in [5] an } \\
\text { ference be } \\
\text { icators for } \\
\text { ctively), wh }\end{array}$ & $\begin{array}{l}\text { LPM regre } \\
\text { was smalle } \\
\text { these two C } \\
\text { nall groups } \\
\text { ive U.S. pat } \\
=3 \& n \\
\text { ectively. St }\end{array}$ & $\begin{array}{l}\text { (both times } 2 \\
\text { ns which carr } \\
\text { ( } n=3 \& n \text { missing), fir }\end{array}$ & $\begin{array}{l}\text { 6] is a dum } \\
\text { the Decem } \\
\text { 2004): larg } \\
\text { me } R \& D(n \\
\text { and which } h \\
n=5 \text { ) and } \\
\text { rapped. }\end{array}$ & $\begin{array}{l}r \text { those firm } \\
004 \text { event. } \\
\text { itive (negat } \\
\text { \& } n=7 \\
\text { ndian paten }\end{array}$ & $\begin{array}{l}\text { the blue and } \\
\text { tical to that } \mathrm{f} \\
\text { which their C } \\
\text { OLS regressi } \\
\text { alues indicate } \\
\text { ), which have } \\
=7 \& n=\end{array}$ & $\begin{array}{l}\text { d arrows in the } \\
\mathrm{r} \text { the blue and red } \\
\mathrm{R} \text { at } t+5 \\
\mathrm{~ns} \text { in [3], [4], [7] and } \\
\text { a significant increase } \\
\text { ome patent(s) } \\
\text { 9). Each model } \\
\text { e statistical }\end{array}$ \\
\hline
\end{tabular}

